\title{
Tutor, teacher, educator in a culturally diverse space of modern education
}

KEYWORDS

tutor, teacher, educator, intercultural competence, intercultural education, educational activities, culturally diverse group
ABSTRACT

The main purpose of this paper is the presentation of selected issues regarding the preparation of tutors, teachers, educators and students who are going to work in the education field and in culturally diverse educational spaces. The first part of the article presents this issue, based on the analysis of the literature. The second part includes examples of initiatives which enable the development of intercultural competence pursued by the author of this paper.

\section{Introduction}

The contemporary space of broadly defined education, which is determined by intensifying migration movements and social-cultural processes, has been changing dynamically. The Currently, the recipients of educational activities are not only the majority or indigenous members of the population, but also gradually increasing groups of foreigners who often communicate in a radically different cultural code. The cultural variety may prove to be an enriching source for both the individual and the society, but it is also a factor that spawns numerous destructive conflicts. A tutor's and educator's job implies the necessity to constantly acquire new knowledge, skills and self-reflection upon own attitudes.

The aim of the article is to present selected issues concerning the essence and the need to acquire new intercultural competence, by people engaged in educational practice, and the exemplification of practical activities for its development. I shall begin by presenting the problem, based on the analysis of the literature and 
afterwards, referring to my own experience, I shall present examples of initiatives that serve the preparation of tutors, teachers, educators and students who wish to seek their future career in education, to work in a diverse environment.

\section{Education and the work of the teaching staff in a multicultural environment: selected issues}

The dynamic social-cultural changes and resulting educational challenges, encourage questions regarding the competence of tutors, teachers and educators, essential for the accomplishment of educational tasks in a diversified space of contemporary education. An examination of the educational practice as well as the analysis of the experience of numerous schools and other education-oriented entities, shows that the "monocultural" educational method does not suffice. An implementation of initiatives, allowing for an effective and inclusive work with individuals of different minority groups, especially groups that, in the words of Geert Hofstede, possess a dramatically different "software of the mind" (see: Hofstede, 2007), face various difficulties (adaptive or/and psychological) as well as groups that are culturally diverse. Both tutors and teachers, engaged in educational practice in terms of formal (school) education as well as tutors engaged in informal education (non-school) $)^{1}$, should possess the knowledge, the skills and the attitude, that will enable the effective work in culturally heterogeneous environments. The task requires a constant development of intercultural competence.

The literature offers a series of definitions used to describe intercultural competence. Stanisław Magala defines intercultural competence in a metaphorical and in result general sense. According to Magala, the competence can be compared to a backpack or a tool box, gradually filled with tools by people when they encounter different "software" of the mind (see Magala 2011). Intercultural education prepares us for establishing a positive relationship with Strangers and Others. This type of education is an attempt to create a society open to diversity, otherness and difference, already at the school level. Learning from Others and learning-teaching Others as a civilisation requirement, may soon become one of the most frequently discussed issues in social debate. (Szczurek-Boruta, 2014: 77). Intercultural education, as a lifelong process of acquiring intercultural competence (Młynarczuk-

\footnotetext{
${ }^{1}$ My use of the term "teaching staff", addresses tutors and teachers possessing specialist knowledge and associated with formal education institutions as well as educators working outside of the formal education scope (non-governmental organisations, culture institutes, etc.) and in local environments, who often lack specialist training.
} 
-Sokołowska, 2015: 72-78), should address all social groups, and be an important element of children, youth and adult education. According to Jerzy Nikitorowicz, it should be dedicated to acquiring competence by teachers, students and parents, including:

- shaping the equality of all cultures and preparing individuals for a peaceful coexistence in a pluralistic society;

- sensitising regarding Otherness, different cultural rooting and tradition as well as shaping of an open and tolerant attitude, enabling the exchange of values, dialogue and negotiation;

- an implementation of self-perception from the perspective of the Other as something enriching and curious rather than hazardous and hostile;

- realising own cultural identity, increasing the feeling of own value, of safety and self-acceptance;

- shaping the skill of problem-solving, regarding prejudice and negative stereotypes that function in a particular society (Nikitorowicz, 2002: 27).

Preparing teachers and in result, other people that work in the field of education, requires a methodical knowledge regarding goals, content, methods, and forms of regional, multicultural and intercultural education. Practical experience acquired through contact with different cultures, foreign language, etc., is also necessary to support the acquired knowledge. Methodical knowledge and practical experience should be considered as an integral element of teaching staff's cultural competence.

Considering the fact, that educational reality is developing dynamically, new groups of foreigners appear in educational institutions, and with them, new challenges regarding educational and didactic tasks, each tutor, teacher and educator should express cognitive and existential self-reliance, and skill in inspiring development and ethical-moral strengthening of individuals they educate (E. Dąbrowa, U. Markowska-Manista, 2010: 47). Beside training of teaching staff for the implementation of intercultural education, as noted by Tadeusz Lewowicki, a certain attitude of readiness is also important (Lewowicki, 2008: 23). The specific content of intercultural education, especially the difficult issues, openly discussed in the public discourse (e.g. the issue of admitting and the integration of refugees), may be met with parents' resistance as well as confusion among teaching staff.

Experience acquired by Polish teachers as well as tutors and educators, regarding working with individuals of different cultures and culturally diverse groups, is affected by various factors: the type and specifics of a school (minority dedicated school, bilingual school, foreign language school, multicultural school), specifics of the region and the type of settlement (frontier, cultural centres) as well as the 
social-cultural diversity of its residents (the proximity of the institution regarding the refugees, the presence of indigenous and new cultural minorities in a majority society), the activity of a school regarding international cooperation (regional, cross-border, EU), the open attitude of the teaching staff towards the multi- and intercultural issues on both local and global level, their ability to acquire knowledge and skills regarding the discussed field (E. Dąbrowa, U. Markowska-Manista, 2010: 48). The aforementioned factors determine various, often varying challenges and educational needs as well as the mode of functioning of a particular institution. One should mention the fact, that working in a culturally diverse environment is a major challenge, as unpredictability and permanent change are its inherent elements. Therefore, it is not possible to prepare the teaching staff for solving every unforeseen situation. Individuals must rely on themselves when searching for solutions to some issues. Individuals characterised by responsibility, the wisdom of referring to the pedagogical knowledge and own experience, that manifest organisational skills (Szcurek-Boruta, 2014: 201) as well as the readiness to self-learning and acquiring additional knowledge, are prepared to face this challenge.

How does the teaching staff evaluate their competence regarding working in a culturally diverse educational space? Results of research, conducted, i.e. by Krystyna Błeszyńska, indicate that individuals engaged in educational practice, who work with culturally diverse groups, insisted on a negative evaluation of their competence in the discussed field. Their negative evaluation was supported by arguments regarding inadequate educational programmes for teachers, the lack of proper methodical programmes and poor access to additional training. The feeling of lack of competence was followed by the feeling of isolation, regarding issues with foreign students. The control group of teachers indicated the need to acquire specific competence and traits crucial for working with a culturally diverse group, namely: foreign language proficiency, knowledge of legal regulations concerning foreign students, cultural competence, the knowledge of the migration and refugee issues, as well as shaping the attitudes of openness, empathy and tolerance (Błeszyńska, 2011: 182). The teachers, prepared only to work in culturally homogeneous environments and establishing monocultural content, are unable to tackle the challenges of the contemporary world. For a long time, Ewa Nasalska has insisted on the necessity of introducing change to the training of teaching staff, including shaping professional competence and developing personality traits, in order to prepare them for showing efficiency in a culturally diverse environment (Nasalska 1999: 79).

The shaping of the teaching staff competence should be implemented by combining theory and practice. Many scholars indicate, that the issues regarding training teachers, are connected with the difficulty of translating the theoretical knowledge 
to educational practice. The research conducted by Alina Szczurek-Boruta, shows that future teachers often indicate the insufficient number of vocational practice, and notice the gap between the realms of theory and practice (Szczurek-Boruta, 2014: 200-201). Regarding this issue, during the training of tutors, teachers and educators for working in multicultural environments, it is imperative to introduce multifaceted education, employing various paradigms and alternative orientations such as: behavioural, humanistic, traditional-apprentice, and reflective (see Zeichner, 1983, cited in: Szczurek-Boruta, 2014: 203). Training of the teaching staff should be accompanied by the development of feelings and sensitivities towards the Other, teaching the art of life, the art of interpersonal and social relationships, anything that determines the culture of mutual cohabitation and the accomplishment of the coexistence paradigm, present in education (Szczurek-Boruta, 2014: 2006). Moreover, one should remember, that each culture should be open to the encounters with other cultures. Only the intercultural interactions allow for the full understanding as well as evaluating the value of own culture, determining own place in consideration of the culture, perfecting and developing culture, and the shaping of open attitudes (Nikitorowicz, 2010: 29).

While educating students at the Faculty of Pedagogy and Psychology, at the University of Białystok, we try to enable them to acquire knowledge and skills imperative for future occupational tasks. Members of the Intercultural Education Department carry out an intercultural education programme. Moreover, preparing the future teaching staff for the inherent challenges regarding working in multicultural environments, takes place during dedicated seminars (i.e. Selected issues regarding working with a minority child, anti-discrimination workshops ${ }^{2}$ ). The Erasmus Plus participants have the opportunity to select dedicated programs (including: Non-formal Intercultural Education ${ }^{3}$, Intercultural Awareness $\left.{ }^{4}\right)$. The important aim of the mentioned seminars is to shape the attitudes of future teaching staff, allowing them to work individually, to expand their own intercultural competence. During the seminars, apart from equipping students with firm theoretical basis, I try to show them the practical possibilities of translating pedagogical theory to educational practice, the principles of designing educational initiatives, my experience in working with educational institutions as well as innovative methods and forms of work. Some of them will be shown below.

\footnotetext{
${ }^{2}$ Extracurricular activities conducted by dr Anna Młynarczuk-Sokołowska, based on an original teaching curriculum.

3 Program conducted by dr Anna Młynarczuk-Sokołowska, based on an original teaching curriculum.

${ }^{4}$ Original program conducted by dr Emilia Żyłkiewicz-Płońska.
} 


\section{The needs and initiatives that serve the purpose shaping of the intercultural competence of the teaching staff and students}

Since 2006 I have been working in the Intercultural Education Department, where my main field of expertise as a theorist is the subject of intercultural education. ${ }^{5}$ Since the beginning of my work I have been following the premise, that theory and practice should maintain in a relation of dialogue. Therefore, my academic career is followed by community service. For years I have been working with the University of Białystok Foundation as well as the Dialogue (Dialog) Foundation'. Pursuing my educational activities, I work with Białystok schools and the Refugee Centre in Białystok. I feel that my community service helps broaden my perspective regarding the subject, that I analyse as a scientist and as an educator. The experience serves as an inspiration for undertaking further scholar activities and improves my academic research and the didactic process. The knowledge and skills related to my scientific pursuits enable me to conduct a careful analysis and interpretation of social-educational issues as well as designing new methodical solutions regarding intercultural education. Combining two perspectives: theoretical and practical, provides me with a sense of reality, sense and the profound nature of conducted activities.

Undertaking initiatives that enable the expansion of intercultural competence of teaching staff and students is an important aspect of my professional and social activity. The knowledge and skills acquired during these activities serve to improve my skills and solving issues that appear in the clash of cultures. I try to design the premises and programmes of the implemented activities, on the base of diagnoses of recent problems and needs, that exist in the local environment and particular institutions.

\section{Training activities}

Experience shows, that the executive branch and the teaching staff most frequently express the need for an analysis of the issues, regarding working with a culturally diverse groups and a supporting, in a broad sense, minority students (including foreigners and refugees). Consquently, during the training initiatives, I focus on

\footnotetext{
${ }^{5}$ My work was preceded by an internship in the Department as well as several years of activity in the Intercultural Education Student Club (including being vice-president).

${ }^{6}$ Since 2010 I have been the vice-president of the University of Białystok Foundation Board. Since 2008, I have been implementing educational activities for the Dialogue (Dialog) Foundation, e.g. as an intercultural counsellor.
} 
the innovative methods of individual and group work in heterogeneous cultural environments. I frequently suggest a method of a modified text, which consists of simplifying the original content (e.g. enumerated in educational programmes), in terms of grammar and vocabulary, reducing their size and designing educational tasks accordingly. The method of text preparation serves to assist the students who fall behind in the curriculum, and help them learn Polish as a second language. The method allows for an educational work adequate to the linguistic and perceptual capabilities of students manifesting specific educational needs (e.g. foreign educational needs). It creates space for a balanced educational opportunity regarding all culturally diverse students in a classroom (Młynarczuk-Sokołowska, Szostak-Król, 2016: pp. 31). The interviews I conducted with teachers, show that, e.g. working using the above-mentioned method helps develop students' motivation and serves the individualisation of teaching. The state of affairs is exemplified by the statement below:

Rahman was failing all the tests. He was using every opportunity to skip classes. If met in the corridor, he would explain that he had religion lessons. Since I began preparing the modified texts and providing him with selected problems for tests, the situation changed dramatically. Rahman started learning. Recently he got an A on a test (... $)^{7}$.

Among the people involved in the educational practice, there is also significant interest in exploring programmes allowing for an intercultural integration. Teachers actively explore pedagogical innovations that they could implement in their workplaces. Individuals working with preschool and early school children, often express the need for exploring the practical applications of the intercultural fairy tales method, which is an integral part of the Adventures of the Other (Przygody Innego $)^{8}$ educational programme. Intercultural fairy tales fit the psychoeducational fairy tale canon. They serve to shape the children's sensitivity towards diversity in many aspects (e.g. interpersonal, economic, cultural). During the 2015/2016 school term, the second edition of the "Adventures of the Other" Programme was placed on the Podlasie Education Office branch list of pedagogical innovations, as a methodical and programmatic innovation. The Concept of Perceiving and Intera-

\footnotetext{
${ }^{7}$ Source: own research.

${ }^{8}$ More on this subject, see: A. Młynarczuk-Sokołowska, K. Potoniec, K. Szostak-Król (eds.), Przygody Innego. Bajki w edukacji międzykulturowej, Białystok 2011; A. Młynarczuk-Sokołowska, K. Potoniec, K.Szostak-Król (eds.), Przygody Innego. Bajki na rzecz integracji dzieci cudzoziemskich, Białystok 2015. The books are available for download in a PDF format, on the University of Białystok PDF website, fundacja. uwb.edu.pl in the Publications (Publikacje) section.
} 
cting with the Other (Koncepcja Postrzegania Innego i Interakcji $z$ Nim by J. Nikitorowicz) is the foundation of the project and determines its contents and direction. The preparation of the intercultural fairy tales and scenarios (for working with the fairy tales, and skill-improving exercises) was accomplished by experienced teachers, educators and academics.

The teaching staff has expressed significant interest in exploring methods for teaching Polish as a second language in an intercultural environment. Since last year, during classes, I have been proposing a method of an intercultural portfolio. The method rests on a systematic documentation of language skills and intercultural experience development, in the form of works gathered in a dedicated folder or binder, by the participants of the learning process. The important element of the method is to monitor and evaluate the progress of own language learning and intercultural communication competence development (see: Młynarczuk-Sokołowska, Szostak-Król, 2016: 50-54). I have designed the method of an intercultural portfolio along with Dr Katarzyna Szostak-Król. Our own notions regarding teaching Polish as a second language to children (especially Chechen and Ukrainian), encouraged us to work on that project. Young foreigners most often develop their communicative skills via additional courses, conducted after class in schools and at the Refugee Centre. While conducting classes of this type, we noticed, that children often lack motivation to learn after class. In result, we asked ourselves a series of questions: What should we do, to encourage children to attend after-class activities regularly? What working model should we introduce in order to motivate them? How to create attractive (from a child's perspective), creative classes, deprived of the feeling of typical feeling of "school pressure"? Development of the intercultural portfolio method was accompanied by a series of scenarios titled To Understand the Other (Zrozumieć Innego), allowing for the development of the intercultural communication competence. The competence consists of elements such as: communicative skill in Polish as well as knowledge of Polish culture and social-cultural reality of living in Poland and in different cultures and countries.

It would be suitable to present particular examples of educational initiatives for teachers and educators.

The Diversity among us (Różnorodność w(śród) nas) project

An important, nationwide activity, in which I took part in 2015-2016, as a regional expert and coordinator regarding intercultural education in Podlaskie Voivodeship, was the Centre of Education Development project called the "Diversity is among 
us"9. The project would include the publishing of the content included in the National Framework for Intercultural Competence. Its main goal was to prepare Polish headmasters, teachers and tutors for the implementation of intercultural education at their workplaces as well as the substantive support, following the undertaken initiatives. Consequently, each Voivodeship recruited its own coordinators, experts regarding intercultural education, responsible for the conducting of a series of training addressing the teaching staff of different schooling levels. The goal of the trained teaching staff was, e.g. to multiply the acquired knowledge and skills among teachers of the same institutions and the initiation of intercultural education.

The first school of intercultural education in Podlasie titled Foreigners in the education space (Cudzoziemcy w przestrzeni edukacji)

The first school of intercultural education in Podlasie proved an important activity, established in 2016. The initiative was designed, based on the analysis of a burning educational issue, regarding the need to prepare teachers, educators and students for working with new groups of refugees (e.g. Syrian an Ukrainian refugees) as well as culturally diverse groups. The activity was conducted in regard of a dedicated training programme, with its framework prepared by myself in cooperation with individuals who deal with the problem of foreigners and refugees, academically and practically. The School Participants had the opportunity to explore the specifics of an asylum procedure in Poland, the issues regarding the reception and integration of refugees; the conditions regarding the war in Syria and Ukraine; selected elements of Syrian, Ukrainian, Chechen and Islam culture; acquire knowledge regarding working with a culturally diverse group and explore the practical application of selected intercultural education methods. The task of each individual, participating in the School project, was to conduct and educational activity in own workplace, addressing children, youth and adults (teachers, parents), based on the new knowledge.

\section{The cyclic educational activities, community service actions and publications}

My attempt is to include students of different fields (pedagogy, social work, Polish philology) of the University of Białystok, in an initiation of community activities in the educational space. Such activities are a result of the concern regarding crea-

\footnotetext{
${ }_{9}$ More about the project, see https://www.ore.edu.pl/programy-i-projekty-77777/roznorodnosc-wsrod-nas, access: 2.04.2016.
} 
ting intercultural competence among children and youth, including the skills purposeful for a peaceful coexistence with Aliens and Others and, at the same time, developing of the methodical, intercultural education approach. The activities are implemented in preschools and schools as well as the Refugee Centre in Białystok. Following the training, students-volunteers begin their work in a particular institution, where they have the chance of "experiencing the practice", and in result, acquire the knowledge and skills that exceed the university programmes. One should mention, that the young people that commit to community service play an exceptionally significant role, regarding the pilot programmes and educational projects as well as verifying new methods. Teachers take part in the aforementioned activities, as they develop their skills, while providing invaluable contribution, supervising the future tutors, teachers and educators. Among the implemented programmes and projects, one should examine those, that enjoy the highest rate of interest by students and teaching staff.

The adventures of the Other (Przygody innego) educational programme

Since 2010, students and teachers have been implementing "The adventures of the Other" educational programme. In some institutions, the project has gained a well-established tradition. The first edition is mostly devoted to indigenous minorities, that live in Poland. The second edition, with its pilot version implemented in 2015, has been implemented in regard of the situation and the chosen foreign cultures. According to opinions by programme participants, the intercultural fairy tales, as the core concepts of the project, enable the possibility of implementing interesting and effective intercultural education activities and the students involve in the project may explore the additional work method "from the inside". A statement by a teacher provides a considerable summary:

(...) For the first time, I have introduced the Adventures of the Other in my class, nearly five years ago. It was a pilot phase of the first edition. Fairy tales are a form of work, close to children, engaging their attention in a natural way. My students listened to the history of the Other with significant interest and experienced his adventures accordingly. The whole cycle of fairy tales is a complete didactic offer for teachers and a significant offer of lessons for children (...) . (...) The University volunteers who worked with me, have learned a lot. It is a chance for them, to explore a new method in practice, and a way to test themselves. ${ }^{10}$.

The programme development was influenced by a continual debate with the city authorities, regarding the conducting of subsequent educational workshops

\footnotetext{
10 Source: own research.
} 
that would have a preventive value for the preschools and schools of Białystok and would prevent the shaping of prejudice and acts of discrimination. Statements by teachers, who expressed the need to expand the activities, regarding the expansion of educational activities, enabling an attractive and accessible introduction of the diversity of the world to children, proved essential.

To Understand the Other (Zrozumieć innego) educational project

Another project, worth mentioning, is an educational project of teaching Polish as a second language in an intercultural context, titled "Understanding the Other". It has been initiated in 2014 by teachers, educators and students-volunteers, associated with the Refugee Centre in Białystok. It is an activity addressing foreign children, aged 9-12, based on the intercultural portfolio method, described above. Statements by students and teachers, who decided to utilise the intercultural portfolio method, lead to a belief, that their lessons are met with a positive reception by children. One of the volunteers, participating in the method claimed:

The method proved successful. Children would voluntarily attend classes. They are eager to place another work into the binder. The binder, or folder; although nothing big; proves to be highly beneficial. The scenarios included in the book (To Understand the Other) are curious. Children are not bored during classes; contrary to ordinary classes, where they are forced to do grammar exercises $(. .)^{11}$.

Variety is the space for dialogue (Różnorodność przestrzenia dialogu) competition

In 2011 along with the Elementary School no. 26, in Podlaskie Voivodeship, we have begun implementing of a continual, literature-art-photography competition titled "Variety is the space for dialogue"12. The initiative is dedicated to preschool and early school children. Its goal is to establish a discussion concerning diversity. Each year, the initiative is established under a different name, e.g. "The other remote and close", "Traditions and customs of the homestead", "favourite fun and games". Thanks to the teacher and/or parental support, children participating in the activities and educational projects present works accordingly to each edition. The highlighted works are presented officially, during a great ball taking place during the World Refugee Day. During the event, children take part in educational fun and game, prepared by students and teachers. The participants' works serve as

\footnotetext{
11 Source: own research.

${ }_{12}$ More on that matter, see the news section of fundacja.uwb.edu.pl.
} 
an inspiration for preparing various didactic tasks in order to open them towards difference. They also motivate towards the discussion regarding the very content. Here is an example of one of the works, presented below:

Family and home; a place where life begins. A place to be remembered (...) Each celebration begins with postcard writing and ends with singing carols or egg-breaking. During national holidays, we hang up the flag, as we consider Poland to be our home (...) Natalia. The "Traditions and customs of a family household"'"13.

\section{Community activities}

I engage my students in activities regarding action, e.g. the actual needs present in educational institutions. Intercultural papers are an example of such activities. During my work at educational institutions, attended by students-refugees, I have noticed that they posses a monocultural nature. That means, that the papers expounded in classrooms and corridors are devoted to the Polish culture only (e.g. holidays, literature). Schools lack works and information regarding the cultural elements of refugee children, which may create a gap for creating relationships with a school. Referring to own observation, I offered students to prepare along with the children, during off-class activities, a number of papers, regarding their own situation and selected elements of culture (e.g. the Chechen culture) that would presumably enrich the iconosphere of schools. A paper titled "Me in a Polish school" would be an important part of the papers. A fragment of one such paper is presented below:

I have lived in Poland for seven years and I feel alright. I attend the sixth grade and I like mathematics the most. I also like sports. My favourite sport is football. I have a lot of friends in class. I'm the only Chechen in class. My friends treat me well. I like, when my teachers help me at school. Islam ${ }^{14}$.

The goal of the described activity was to develop a feeling of identity within the foreign students, a feeling that the school they attend to is also theirs, and to introduce the knowledge concerning their heritage to Polish students. After a while, placing the papers showed additional results. The content of the papers proved interesting for students, teachers and school personnel.

\footnotetext{
${ }_{13}$ Source: project archive.

${ }^{14}$ Source: project archive.
} 
Scientific-methodical publications

My goal is to design educational activities in such way, that their results would be published as scientific-methodical or methodical articles. Me and my associates (academics, teachers, educators, etc.) intend to share the experience and methodical solutions we managed to develop. Our published articles are a source of knowledge regarding the issues of the cultural diversity education and provide a useful tool of working in an intercultural environment. In order to reach a broader audience, we distribute our works free of charge. Our most recent scientific-methodical publications consist of: To Understand the Other. Intercultural communicative competence in the process of teaching polish as a second language. (Zrozumieć Innego. Międzykulturowa kompetencja komunikacyjna w procesie nauczania języka polskiego jako obcego) (2016); The adventures of the Other. Intercultural fairy tales for the integration of foreign children (Przygody Innego. Bajki międzykulturowe na rzecz integracji dzieci cudzoziemskich) (2015); Diversity. Creative activity. Inclusion in education (Różnorodność. Twórcza aktywność. Inkluzja w edukacji) (2013) ${ }^{15}$.

\section{Conclusion}

Working in a culturally diverse environment, characterised by unpredictability and numerous challenges, is a task that requires skill and an open attitude from tutors, teachers and educators alike. There is not single, universal programme and methodical model that would enable individuals to manage in the varying situations that occur regarding the cross-border situations. In a dynamically changing social-cultural reality it is difficult to obtain the education or training, that would be found sufficient. Competence of individuals engaged in educational practice (including the intercultural), should be subject to constant development according to the life-span education and the self-education of individuals, regarding the acquiring of theoretical knowledge and practical experience in their mutual relations. It is imperative to utilise the potential in culturally diverse groups, coordinated by the teaching staff as well as to explore own, culturally sensitive methodical solutions. It is also crucial to cooperate and share experience with institutions (e.g. non-governmental organisations), who, based on their educational practice, formed innovative programmes, projects and methods, serving the implementation of intercultural education.

\footnotetext{
${ }_{15}$ The publications mentioned, are available at the University of Białystok Foundation website: fundacja.uwb.edu.pl, section: Publications (Publikacje). Book ordering of the :Przygody Innego. Bajki międzykulturowe na rzecz integracji... is available (printed version). Further information at: fundacja.uwb. edu.pl, Publication (Publikacje) section as well as www.mentoring.pl
} 


\section{References}

Błeszyńska K. M. (2011). Dzieci imigrantów i uchodźców jako grupa zagrożona wykluczeniem edukacyjnym. [in:] Pedagogika międzykulturowa wobec wykluczenia społecznego i edukacyjnego, (eds.) T. Lewowicki, A. Szczurek-Boruta, J. Suchodolska . Cieszyn-Warszawa-Toruń, p. 182.

Dąbrowa E., Markowska-Manista U. (2010). Przygotowanie nauczycieli do pracy w wielokulturowej rzeczywistości w perspektywie standardów europejskich. [in:] Szkoła i nauczyciele wobec problemów edukacji międzykulturowej, ed. Z. Jasiński. Opole, p. 47.

Hofstede G. (2007). Kultury i organizacje. Warszawa 2007.

Lewowicki T. (2008). O podstawowych warunkach pomyślnej pracy nauczycieli w sytuacji wielokulturowości. [in: ] Praca nauczyciela $w$ warunkach wielokulturowości - studia i doświadczenia z pogranicza polsko-czeskiego, (eds.) T. Lewowicki, E. Ogrodzka-Mazur, A. Szczurek-Boruta, Toruń, p. 23.

Magala S. (2011). Kompetencje międzykulturowe, Warszawa 2011, p. 40.

Młynarczuk-Sokołowska A. (2015). Od obcości do inności. Międzykulturowa edukacja nieformalna na przykładzie działań polskich organizacji pozarządowych, Warszawa, pp. 72-78.

Młynarczuk-Sokołowska A., Szostak-Król K. (2016). Zrozumieć Innego. Międzykulturowa kompetencja komunikacyjna w procesie uczenia się języka polskiego jako obcego, Białystok 2016, pp. 31.

Nasalska E. (1999). Edukacja międzykulturowa w polskiej szkole, „Kwartalnik Pedagogiczny” vol 1, p. 79.

Nikitorowicz J. (2002). Edukacja międzykulturowa wobec dylematów kształtowania tożsamości w społeczeństwach wielokulturowych. [in:] Edukacja wobec ładu globalnego, eds. T. Lewowicki, J. Nikitorowicz, J. Pilch, S. Tomiuk. Warszawa, p. 27.

Nikitorowicz J. (2010). Współczesny nauczyciel w procesie rewitalizacji wartości i pamięci przeszłości w kreującym się społeczeństwie wielokulturowym. [in:] Szkoła i nauczyciele wobec problemów edukacji międzykulturowej, ed. Z. Jasiński. Opole, p. 29.

Szczurek-Boruta A. (2014). O przygotowaniu nauczycieli do pracy w warunkach wielokulturowości, ed. Adam Marszałek, Toruń, p. 77.

Zeichner K.M. (1983). Alternative Paradigms of Teacher Education, „Journal of Teacher Education”, vol. XXXIV, cited in: Szczurek-Boruta A. (2014). O przygotowaniu nauczycieli do pracy w warunkach wielokulturowości, Toruń, p. 203.

\section{Web sources}

Różnorodność wśród nas, see: https://www.ore.edu.pl/programy-i-projekty-77777/roznorodnosc-w-srod-nas, access date: 2.04.2016.

\section{Empirical evidence}

The content of open interviews, conducted during social activities regarding intercultural education (training, educational projects and programmes, etc.) for tutors, teachers, educators and students.

The archival sources regarding activities in the field of intercultural education for students of Podlasie schools. 